\title{
The Relationship Between TSH Levels and Body Mass Index in Overweight Euthyroid Subjects: Role of Autoimmunity
}

\author{
Loviselli A*, Sainas GM, Magnani S, Secci G, Pisanu S, Deledda A, Boi A, Lai D and Velluzzi F
}

${ }^{1}$ UO Obesità, Dipartimento di Scienze Mediche e Sanità Pubblica, Università di Cagliari, Via Ospedale 120, 09127 Cagliari

Received: March 23, 2018; Accepted: April 04, 2018; Published: April 19, 2018

*Corresponding author: Andrea Loviselli, Dipartimento di Scienze Mediche e Sanità Pubblica, University of Cagliari, SS 554,Monserrato, Cagliari, Italy.Telephone: +39070 6092258;E-mail: alovise2@gmail.com

\section{Abstract}

Summary: Also if a positive correlation between TSH and BMI has been observed in the majority of the studies, data on this topic remain controversial, especially when TSH values are in normal range. However, it is reasonable to argue that the high-normal levels of TSH found in obesity can be partly attributed to a silent autoimmune thyroiditis. The aim of the present study was to evaluate the interconnection between TSH and autoimmunity in obese patients with TSH values within the normal range.

Methods: We enrolled 891 overweight and obese patients (209 Males), with TSH values in normal range (mean age \pm SD: $45.1 \pm 15$ years. Anti thyroid auto antibodies(ATAs: thyroid-peroxides auto antibodies (TPOAb) and/or thyroglobulin auto antibodies(TgAb) and TSH were measured in all patients. The entire sample was then subdivided according to the tertiles of TSH within the range between 0.4 and $4.1 \mu \mathrm{UI} / \mathrm{L}$.

Results: No significant correlation between TSH and BMI was found within these groups. According to the presence (ATA+) or absence (ATA-) of ATAs, we found $225(25,4 \%)$ ATA+ (32 males) and 665 ATA- (177 males) patients. A statistically significant correlation between TSH and BMI was found only in females with ATA positivity (Pearson: $r=0.1426, p=0.04$; Spearman: $r=0.1616, p=0.02$ ).

Conclusion: In the initial assessment of obesity, the determination of TSH could be associate to ATAs, for identifying, among the patients with increased TSH, those affected by autoimmune thyroiditis. We suggest that in these patients, the beginning of LT4 therapy could be taken into account.

Keywords: TSH; Obesity; Autoimmunity

\section{Introduction}

Overweight and obesity are defined as "abnormal or excessive fat accumulation that may impair health" [1].

This condition leads to adipocyte hypertrophy, resulting in dysfunction of white adipose tissue, development of hypoxia, oxidative stress and inflammation [2,3]. Fat tissue dysfunction can lead to metabolic changes in several organs and systems, among which in the endocrine system where changes in plasma levels, secretion patterns and clearance of different hormones are observed $[4,6]$.
As far as thyroid function is concerned, literature data suggest either a possible influence of obesity on the hypothalamicpituitary-thyroid axis (HPT) or vice versa of thyroid on the development and maintenance of obesity [7-15]. It has also been documented that even minimal changes in the HPT axis and/or in thyroid function with hormone levels in the reference range can be positively associated with components of metabolic syndrome and an increase in the risk of thyroid cancer [16-20].

In addition, specific TSH receptors have recently been found on adipose tissue, suggesting a direct role of TSH on adipocyte function and energy expenditure [21].

Several clinical and population studies have shown positive correlation between TSH and BMI, but this is in contrast with other clinical and population studies, in which this correlation was not found[22-47].

It is known that Hashimoto's thyroiditis (HT) is the main cause of thyroid function failure, with a consequent increase in TSH values [48-50]. Since it has been hypothesized that obesity can trigger or make manifest an autoimmune process, it is reasonable to argue that the high-normal levels of TSH found in obesity can be partly attributed to a silent autoimmune thyroiditis [43,5162]. This condition may be revealed by positive anti thyroid antibodies (ATA) whose prevalence increases with age and is greater in female subjects [63,64-66].

Nevertheless, few studies have considered autoimmunity in the context of the complex relationship between excessive weight and thyroid disease $[10,33,41-43]$. This might partly explain the discordance of literature data on the relationship between BMI and TSH. With regard to this, the association between body mass and subclinical autoimmune hypothyroidism would seem to be conceivable in patients with less pronounced adiposity, since it was not observed in a study that selected patients with Class III obesity and elevated levels of TSH. Moreover, Rotondi et al [43]. showed that thyroid ultrasound in obese patients is a confounding factor in the diagnosis of HT, so that only auto antibodies should be used to identify the underlying thyroid disease. Given that in Sardinia there is a high prevalence of autoimmune diseases and an increasing prevalence of obesity, the greater prevalence 
of both conditions, could allow a greater statistical power to the study of the relationship between TSH levels and autoimmunity in obese and overweight patients [67-71,72]. In the present study we considered exclusively patients with TSH values within the conventional normal range in order to elucidate the relationship between excessive body weight and high-normal TSH levels and the influence of autoimmunity on this relationship.

\section{Materials And Methods}

\section{Patient's Enrolment}

From a total population of 1246 outpatients consecutively afferent at the Obesity Operating Unit (University of Cagliari; Italy) from 2014 to 2016; we excluded 13 patients with known history of hypothyroidism or hyperthyroidism; 184 patients with diabetes mellitus;[73]15 underweight and 22 normal weight patients.

According to the purpose of the present study; other 121 patients; having abnormal serum TSH concentration $(<0.4 \mu \mathrm{UI} / \mathrm{L}$; $\mathrm{n}=64)$ or $>4.1 \mu \mathrm{UI} / \mathrm{L} ; \mathrm{n} .=57)$ were excluded.

Thus the study group consisted of 891 patients (209 Males); with TSH values between 0.4 and $4.1 \mu \mathrm{UI} / \mathrm{L}$. None subjects was taking drugs affecting thyroid function [66]

The age of males ranged between 19 and 78 years (mean \pm SD $45.1 \pm 15$ years); the age of females ranged between 13 and 80 years (mean \pm SD $44.8 \pm 14.8$ years).

On the basis of the body mass index (BMI); calculated as weight $(\mathrm{Kg})$ / height (m2); 126 patients (11 males) were overweight (BMI 25.0-29.9 kg/m²) and 765 (198 males) obese (BMI $\geq 30 \mathrm{~kg} / \mathrm{m}^{2}$ ); further categorized according to WHO criteria [1] in:

298 (74 Males) with Class I obesity (BMI $30.0-34.9 \mathrm{~kg} / \mathrm{m}^{2}$ ); 263 (61 Males) with Class II obesity (BMI $35.0-39.9 \mathrm{~kg} / \mathrm{m}^{2}$ ); 204 (63 Males) with Class III obesity (BMI $\geq 40 \mathrm{~kg} / \mathrm{m}^{2}$ ).

Clinical data (systolic and diastolic blood pressure; heart rate) and biochemical data (fasting glucose; total and HDL cholesterol; triglycerides; alanin- aminotrasferase aspartateaminotrasferase; blood count; uric acid levels) have been evaluated but not considered in the study.

\section{Thyroid Evaluation}

Venous blood samples for hormonal and antibodies determinations; as well as for the above mentioned blood chemical parameters; were taken from the antecubital vein of the arm in fasting condition between 08:00 and 09:00 a.m.; hormone values and antibodies were tested using commercial kits.

Anti thyroid auto antibodies (ATAs: thyroid-peroxidise auto antibodies [TPOAb] and/or thyroglobulin auto antibodies [TgAb]) were measured with chemiluminiscence methods (TPOAb and TgAb by Immulite 2000; Diagnostic Products Corporation; Los Angeles; CA; USA; Distributor Medical Systems Corporation; Genoa; Italy); considering the following as normal values: $\operatorname{TgAb}$ 20-40; TPOAb 10-35 UI/ml.

Serum thyroid stimulating hormone (TSH) has been analysed by ultra-sensitive automatic chemiluminiscence (Ortho Clinical Diagnostic SpA; Milan; Italy). The sensitivity was $0.004 \mu \mathrm{UI} / \mathrm{L}$ and the normal values were 0.4-4.1 $\mu \mathrm{UI} / \mathrm{L}$.

\section{Statistical Analysis}

Results for quantitative variables are expressed as mean \pm SD for normally distributed data; and mean (Interquartile range) for non-parametric data. The regulation at normal distribution was tested with the Kolmogorov-Smirnov (K-S) test.

Data were analysed by using Student's t-test for unpaired data and relationship between quantitative variable by regression analysis with Pearson and Spearman correlation methods.

For all tests; a p- value $<0.05$ was considered as a limit of significance.

The statistical analysis was performed using commercial software (Graph-Pad; Prism).

\section{Results}

TSH concentrations (Mean \pm SD) among patients categorized in 4 groups on the basis of BMI were found to be overlapped in all groups (Table 1).

Table 1: TSH concentrations $(\mathrm{M} \pm \mathrm{SD})$ among patients in the various categories of BMI

\begin{tabular}{|c|c|}
\hline Category BMI & TSH concentrations (M \pm SD) \\
\hline Overweight & $2.27 \pm 1.82 \mu \mathrm{UI} / \mathrm{L}$ \\
\hline Class I obesity & $2.14 \pm 1.50 \mu U \mathrm{UI} / \mathrm{L}$ \\
\hline Class II obesity & $2.12 \pm 1.97 \mu U I / \mathrm{L}$ \\
\hline Class III obesity & $2.31 \pm 1.53 \mu U I / L$ \\
\hline
\end{tabular}

(The entire sample was then subdivided according to the tertiles of TSH within the range between 0.4 and $4.1 \mu \mathrm{UI} / \mathrm{L}$; the comparison of the BMI mean values in the three subgroups thus obtained did not show any significant statistical difference:

1) In the 1st tertile (TSH: 0.4-1.36 $\mu \mathrm{UI} / \mathrm{L}$ ) including 251 patients (75 Males) the BMI was found to be $35.4 \pm 6.68 \mathrm{Kg} / \mathrm{m}^{2}$;

2) In the 2nd tertile (TSH: 1.37-2.73 $\mu \mathrm{UI} / \mathrm{L}$ ) including 477 patients (107 Males) the BMI was found to be $35.7 \pm 6.71 \mathrm{Kg} / \mathrm{m}^{2}$;

3) In the 3rd tertile (TSH: 2.74-4.1 $\mu \mathrm{UI} / \mathrm{L}$ ) including 163 patients (27 Males) the BMI was found to be $35.7 \pm 6.48 \mathrm{Kg} / \mathrm{m}^{2}$.

No statistically significant correlation between TSH and BMI was found within these groups (data not shown).

According to the presence (ATA+) or absence (ATA-) of ATAs; our population included $225(25 ; 4 \%)$ ATA+ (32 males) and 665 (74.6\%) ATA- (177 males) patients.

The mean values of TSH and BMI (Table 2); were almost overlapped in the two groups $(\mathrm{p}=0.67 ; \mathrm{p}=0.43$; respectively); but dividing both groups (positive and negative ATA) by gender; a statistically significant correlation between TSH and BMI was observed only in females with ATA positivity (Pearson: $r=$ $0.1426 ; 95 \%$ IC $(0.0025 ; 0.2773)$ (Figure 1); $p=0.04$; Spearman: $r$ $=0.1616 ; 95 \%$ IC $(0.1775 ; 0.2989) ; p=0.02)$. No correlation was observed in negative ATA patients of both genders. 
Table 2: $\mathrm{BMI}$ and $\mathrm{TSH}$ values concentrations $(\mathrm{M} \pm \mathrm{SD})$ in

ATA+ and ATA- patients

\begin{tabular}{|c|c|c|}
\hline & BMI $(\mathbf{M} \pm \mathbf{S D})$ & TSH \\
\hline ATA + & $35.1 \pm 6.6 \mathrm{Kg} / \mathrm{m}^{2}$ & $2.03 \pm 0.9 \mu \mathbf{U I} / \mathrm{L}$ \\
\hline ATA - & $35.2 \pm 6.5 \mathrm{Kg} / \mathrm{m}^{2}$ & $2.00 \pm 0.8 \boldsymbol{\mu U I} / \mathrm{L}$ \\
\hline
\end{tabular}

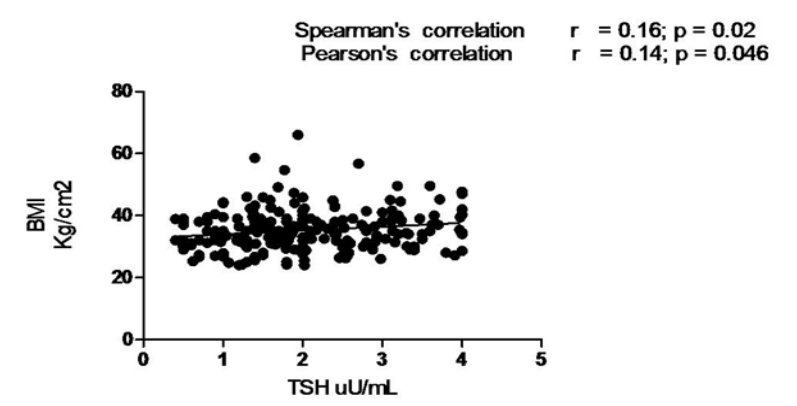

Figure 1: Correlation between TSH $(0.4-4.1 \mu \mathrm{U} / \mathrm{L})$ and BMI in ATA positive females patients.

\section{Discussion}

In our work we found that a significant; yet weak; positive correlation between TSH and BMI is limited to ATA positive female patients.

This result can be justified by the observations of Spencer et al. in NHANES study [74]: for each age and ethnic group; the inclusion of antibody positive subjects shifted the medians and upper limits of TSH ( 97.5 percentile) to the right; while it had no effect on the lower limits (2.5 percentile). Moreover; it is well known that thyroid autoimmunity is more frequent in females [64-66].

The close association between the presence of Hashimoto's thyroiditis and increased levels of TSH has been strangely neglected or underestimated by the majority of authors who studied the complex relationships between thyroid and excessive weight.

In fact; only five studies; out of which three clinical trials and two performed in general population; evaluated the presence of ATAs and consequently verified whether the correlation between TSH and BMI was affected. Regarding the clinical trials; in the study of Manji et al. on 267 British euthyroid patients; tested for ATA out of whom only 35 resulted positive; no correlation between TSH and BMI was found. Also Michalaki et al. in the same year; did not observe any correlation between TSH and BMI in 144 large obese people of Greek ethnicity; selected for euthyroidism and ATA negativity. Finally in a subsequent study conducted by Rotondi et al. on 350 obese Italian subjects; out of whom 40 were ATA positive; no correlation between TSH and BMI was observed; even though the average TSH values were higher in obese than in the normal-weight Individuals [41-43]. However; the authors did not separate positive ATAs patients (numerically poorly represented) from negative ATAs patients. Furthermore; the prevalence of ATA in obese subjects overlapped that observed in the general population; while in patients with subclinical hypothyroidism the authors reported a higher prevalence of ATA in normal weight $(66.1 \%)$ than in obese individuals $(32.1 \%)$. They concluded that autoimmunity weakly influences the behaviour of TSH in obesity.

In partial accordance with our data; Diez et al. examined 778 Spanish obese euthyroid patients; enrolled in a "Thyroid clinic"[75]. ATA were measured on 412 patients; out of whom 46 were positive. A significant correlation between TSH and BMI was found in the obese patients of both genders but no correlation was observed in negative ATA patients; although the number of positive patients was really small. In addition; the influence of thyroid autoimmunity on the relationship between BMI and TSH was underlined by the higher TSH values in patients with positive autoimmunity compared to patients with negative autoimmunity.

Inconsistent results on the relationship between serum TSH and obesity are also reported in population studies. In 2005; Knudsen et al. examined a population of 4082 aged 1865 years Danish people. The sample was drawn among women in the age groups 18-22; 25-30; 40-45; and 60-65 years; with the aim to represent women before child bearing age; within childbearing age; after childbearing age but premenopausal; and postmenopausal [33]. A group of men aged 60-65 years was included for comparison between genders. The preponderance of women chosen for this study was due to the higher prevalence of thyroid abnormalities expected in female sex; with the aim to increase the statistical power of the study at the lowest cost. Likewise; the group of men was chosen in the age group with the highest expected prevalence of thyroid abnormalities.

These authors found a positive correlation between TSH and BMI; but; although ATAs were assessed; the results are surprisingly not reported; and therefore it is not possible to highlight the potential influence of ATA.

In the study of Kitahara et al. [10] on 3114 Americans over the age of 20 years; a positive correlation between TSH and BMI was found; but excluding the 325 ATA positive subjects; it surprisingly decreased significantly in females; while remained unchanged in males. Finally; although Diez et al [75] opens a key reading of these conflicting results; arguing that autoimmunity can influence the correlation between TSH and BMI; he does not expose a sufficient demonstration of this assumption. In fact; the number of positive ATA subjects is too low to justify the great difference in the results obtained after the exclusion of the positive ATAs.

In our study; the presence of thyroid autoimmunity in obese and overweight patients; similar to that observed in our previous study performed in the general population [68]; influences the relationship between TSH and body mass.

The high prevalence of autoimmunity in Sardinia; allowed to highlight an association between excessive weight and autoimmune thyroid disease; which in other ethnicities with a lower prevalence was not observed and therefore denied [43]. However; the observed association was weak. This can be partly explained by the range restriction of TSH values; considering that the value of $r$ can be lower if the variability among the observations is small[68]. 
A possible limitation of the present study is the lack of thyroid hormones assay in our patients. However; considering that we enrolled only subjects with normal TSH levels; and given that the central hypothyroidism is extremely rare in the population; we considered this analysis not relevant. Furthermore; a considerable variability of thyroid hormones; as a result of the nutritional status; has been reported in obesity [15].

In overweight and obese patients; the determination of TSH should be associated to ATAs; for identifying; among the patients with increased TSH; those affected by autoimmune thyroid disease. The low employment of this diagnostic tool and the resulting lack of this information could partly explain the discrepancy of the results obtained by the researchers with regard to the relationship between TSH and BMI in obese population.

Particularly in obese ATA positive women; high normal TSH levels could be attributed to a slight thyroid failure; while in all other cases obesity per sè could play a pivotal role [76]; confirming in a larger number of obese patients; the hypothesis of Diez et al (68) that the relationship between TSH and BMI could be due to the presence of underlying autoimmune thyroid disease. This consideration is supported by the reduction of TSH levels in obese patients undergoing bariatric surgery with exception of those affected by autoimmune thyroid disease $[73 ; 76 ; 77]$

\section{Conclusion}

In conclusion our results suggest the importance of the systematic evaluation of thyroid autoimmunity in addition to that of TSH; in the analysis of the complex relationship between thyroid and body weight.

\section{Acknowledgments}

Authors thank Prof. Stefano Mariotti for his contribution to study design.

\section{Conflict of Interest}

The authors declare that they have no conflict of interest.

\section{Ethical approval}

All procedures performed in studies involving human participants were in accordance with the ethical standards of the institutional and/or national research committee and with the 1964 Helsinki declaration and its later amendments or comparable ethical standards.

\section{Informed consent}

Informed consent was obtained from all individual participants included in the study.

\section{References}

1. World Health Organization. "Definition Overweight and obesity". 2017.

2. Gregor MF, Hotamisligil GS. Inflammatory mechanisms in obesity. Annu Rev Immunol. 2011;29:415-445. Doi: 10.1146/annurevimmunol-031210-101322

3. Ruperez AI, Gil A, Aguilera CM. Genetics of oxidative stress in obesity. Int J Mol Sci. 2014;15 (2):3118-3144. Doi: 10.3390/ijms15023118
4. Bays HE, Gonzalez-Campoy JM, Bray GA, Kitabchi AE, Bergman DA, Schorr AB, et al. Pathogenic potential of adipose tissue and metabolic consequences of adipocyte hypertrophy and increased visceral adiposity. Expert Rev Cardiovasc Ther. 2008;6 (3):343-368. Doi:10.1586/14779072.6.3.343

5. Trayhurn P. Hypoxia and adipose tissue function and dysfunction in obesity. Physiol Rev. 2013;93(1):1-21. Doi:10.1152/ physrev.00017.2012

6. Fierabracci P, Pinchera A, Martinelli S, Scartabelli G, Salvetti G, Giannetti M, et al. Prevalence of endocrine diseases in morbidly obese patients scheduled for bariatric surgery: beyond diabetes. Obes Surg. 2011;21(1):54-60. Doi:10.1007/s11695-010-0297-6

7. Betry C, Challan-Belval MA, Bernard A, Charrie A, Drai J, Laville M, et al. Increased TSH in obesity: Evidence for a BMI-independent association with leptin. Diabetes Metab. 2015;41(3):248-251. Doi:10.1016/j. diabet.2014.11.009

8. de Moura Souza A, Sichieri R. Association between serum TSH concentration within the normal range and adiposity. Eur J Endocrinol. 2011;165 (1):11-15. Doi:10.1530/EJE-11-0261

9. Fontenelle LC, Feitosa MM, Severo JS, Freitas TE, Morais JB, Torres-Leal FL, et al. Thyroid Function in Human Obesity: Underlying Mechanisms. Horm Metab Res. 2016;48(12):787-794. Doi:10.1055/s-0042-121421

10. Kitahara CM, Platz EA, Ladenson PW, Mondul AM, Menke A, Berrington de Gonzalez A. Body fatness and markers of thyroid function among U.S. men and women. PLoS One. 2012;7(4):e34979. Doi:10.1371/ journal.pone.0034979

11. Lambrinoudaki I, Armeni E, Rizos D, Georgiopoulos G, Athanasouli $\mathrm{F}$, Triantafyllou $\mathrm{N}$, et al. Indices of adiposity and thyroid hormones in euthyroid postmenopausal women. Eur J Endocrinol. 2015;173(2):237-245. Doi:10.1530/EJE-15-0141

12. Muscogiuri G, Sorice GP, Mezza T, Prioletta A, Lassandro AP, Pirronti T, et al. High-normal TSH values in obesity: is it insulin resistance or adipose tissue's guilt? Obesity (Silver Spring). 2013;21(1):101-106. Doi:10.1002/oby.20240

13. Ren R, Jiang X, Zhang X, Guan Q Yu C, Li Y, et al. Association between thyroid hormones and body fat in euthyroid subjects. Clin Endocrinol (Oxf). 2014;80(4):585-590. Doi:10.1111/cen.12311

14. Rotondi M, Magri F, Chiovato L. Thyroid and obesity: not a oneway interaction. J Clin Endocrinol Metab. 2011;96(2):344-346. Doi:10.1210/jc.2010-2515

15. Santini F, Marzullo P, Rotondi M, Ceccarini G, Pagano L, Ippolito S, et al. Mechanisms in endocrinology: the crosstalk between thyroid gland and adipose tissue: signal integration in health and disease. Eur J Endocrinol. 2014;171 (4):R137-152. Doi:10.1530/EJE-14-0067

16. Marcello MA, Cunha LL, Batista FA, Ward LS. Obesity and thyroid cancer. Endocr Relat Cancer. 2014;21(5):T255-271. Doi:10.1530/ ERC-14-0070

17. Oh JY, Sung YA, Lee HJ. Elevated thyroid stimulating hormone levels are associated with metabolic syndrome in euthyroid young women. Korean J Intern Med. 2013;28(2):180-186. Doi:10.3904/ kjim.2013.28.2.180

18. Roef GL, Rietzschel ER, Van Daele CM, Taes YE, De Buyzere ML, Gillebert TC, et al. Triiodothyronine and free thyroxine levels are differentially associated with metabolic profile and adiposity-related 
cardiovascular risk markers in euthyroid middle-aged subjects. Thyroid. 2014;24(2):223-231. Doi:10.1089/thy.2013.0314

19. Taylor PN, Razvi S, Pearce SH, Dayan CM. Clinical review: A review of the clinical consequences of variation in thyroid function within the reference range. J Clin Endocrinol Metab. 2013;98(9):3562-3571. Doi:10.1210/jc.2013-1315

20. Wang X, Liu H, Chen J, Huang Y, Li L, Rampersad S, Qu S. Metabolic Characteristics in Obese Patients Complicated by Mild Thyroid Hormone Deficiency. Horm Metab Res. 2016;48(5):331-337. Doi:10.1055/s-0042-105150

21. Draman MS, Stechman M, Scott-Coombes D, Dayan CM, Rees DA, Marian Ludgate et al. The Role of Thyrotropin Receptor Activation in Adipogenesis and Modulation of Fat Phenotype. Front Endocrinol (Lausanne). 2017;8:83. Doi: 10.3389/fendo.2017.00083

22. Ambrosi B, Masserini B, Iorio L, Delnevo A, Malavazos AE, Morricone $\mathrm{L}$, et al. Relationship of thyroid function with body mass index and insulin-resistance in euthyroid obese subjects. J Endocrinol Invest. 2010;33(9):640-643. Doi: 10.3275/6952

23. Bastemir M, Akin F, Alkis E, Kaptanoglu B. Obesity is associated with increased serum TSH level, independent of thyroid function. Swiss Med Wkly. 2007;137(29-30):431-434. Doi:2007/29/smw-11774

24. Chikunguwo S, Brethauer S, Nirujogi V, Pitt T, Udomsawaengsup $\mathrm{S}$, Chand $\mathrm{B}$, et al. Influence of obesity and surgical weight loss on thyroid hormone levels. Surg Obes Relat Dis. 2007;3(6):631-635. Doi:10.1016/j.soard.2007.07.011

25. Dvorakova M, Hill M, Cerovska J, Pobisova Z, Bilek R, Hoskovcova P, et al. Relationship between pituitary-thyroid axis hormones and anthropometric parameters in Czech adult population. Physiol Res. 2008;57(Suppl 1):S127-134

26. Galofre JC, Pujante P, Abreu C, Santos S, Guillen-Grima F, Fruhbeck G, Salvador J. Relationship between thyroid-stimulating hormone and insulin in euthyroid obese men. Ann Nutr Metab. 2008;53(3-4):188194. Doi:10.1159/000172981

27. Gopinath B, Liew G, Flood VM, Wang JJ, Kifley A, Leeder SR, et al. The association between weight gain and thyroid function in an older population. Arch Intern Med.2008;168(20):2283-2284. Doi: 10.1001/ archinte.168.20.2283

28. Iacobellis G, Ribaudo MC, Zappaterreno A, Iannucci CV, Leonetti F. Relationship of thyroid function with body mass index, leptin, insulin sensitivity and adiponectin in euthyroid obese women. Clin Endocrinol (Oxf). 2005;62(4):487-491. Doi:10.1111/j.1365-2265.2005.02247.x

29. Kouidhi S, Berhouma R, Ammar M, Rouissi K, Jarboui S, ClergetFroidevaux MS, et al. Relationship of thyroid function with obesity and type 2 diabetes in euthyroid Tunisian subjects. Endocr Res. 2013;38(1):15-23. Doi: 10.3109/07435800.2012.699987

30. Ruscica M, Dozio E, Gandini S, Gnocchi P, Devalle GG, Motta M, et al. Total, free and bound leptin and thyroid function in elderly women with different body weights. Clin Endocrinol. 2008;68(6):1002-1008. Doi:10.1111/j.1365-2265.2007.03133.x

31. Solanki A, Bansal S, Jindal S, Saxena V, Shukla US. Relationship of serum thyroid stimulating hormone with body mass index in healthy adults. Indian J Endocrinol Metab. 2013;17(Suppl 1):S167-169. Doi:10.4103/2230-8210.119560

32. Fox CS, Pencina MJ, D’Agostino RB, Murabito JM, Seely EW, Pearce EN, et al. Relations of thyroid function to body weight: cross-sectional and longitudinal observations in a community-based sample. Arch Intern Med. 2008;168 (6):587-592. Doi:10.1001/archinte.168.6.587

33. Knudsen N, Laurberg P, Rasmussen LB, Bulow I, Perrild H, Ovesen $\mathrm{L}$, et al. Small differences in thyroid function may be important for body mass index and the occurrence of obesity in the population. J Clin Endocrinol Metab. 2005;90(7):4019-4024. Doi:10.1210/jc.20042225

34. Lee YK, Kim JE, Oh HJ, Park KS, Kim SK, Park SW, et al. Serum TSH level in healthy Koreans and the association of TSH with serum lipid concentration and metabolic syndrome. Korean J Intern Med. 2011;26(4):432-439. Doi:10.3904/kjim.2011.26.4.432

35. Nyrnes A, Jorde R, Sundsfjord J. Serum TSH is positively associated with BMI. Int J Obes (Lond). 2006;30(1):100-105. Doi: 10.1038/ sj.ijo.0803112

36. Ruhla S, Weickert MO, Arafat AM, Osterhoff M, Isken F, Spranger J, Schofl C, Pfeiffer AF, Mohlig M. A high normal TSH is associated with the metabolic syndrome. Clin Endocrinol (Oxf). 2010;72(5):696-701. Doi:10.1111/j.1365-2265.2009.03698.x

37. Svare A, Nilsen TI, Bjoro T, Asvold BO, Langhammer A. Serum TSH related to measures of body mass: longitudinal data from the HUNT Study, Norway. Clin Endocrinol (Oxf). 2011;74(6):769-775. Doi:10.1111/j.1365-2265.2011.04009.x

38. Bakiner O, Bozkirli E, Cavlak G, Ozsahin K, Ertorer E. Are plasma thyroid-stimulating hormone levels associated with degree of obesity and metabolic syndrome in euthyroid obese patients? A Turkish cohort study. ISRN Endocrinol. 2014;2014:803028. Doi:10.1155/2014/803028

39. De Pergola G, Ciampolillo A, Paolotti S, Trerotoli P, Giorgino R. Free triiodothyronine and thyroid stimulating hormone are directly associated with waist circumference, independently of insulin resistance, metabolic parameters and blood pressure in overweight and obese women. Clin Endocrinol (Oxf). 2007;67(2):265-269. Doi: 10.1111/j.1365-2265.2007.02874.x

40. Duntas L, Hauner H, Rosenthal J, Pfeiffer EF. Thyrotropin releasing hormone (TRH) immunoreactivity and thyroid function in obesity. Int J Obes. 1991;15(1):83-87

41. Manji N, Boelaert K, Sheppard MC, Holder RL, Gough SC, Franklyn JA. Lack of association between serum TSH or free T4 and body mass index in euthyroid subjects. Clin Endocrinol (Oxf). 2006;64(2):125128. Doi: $10.1111 /$ j.1365-2265.2006.02433.x

42. Michalaki MA, Vagenakis AG, Leonardou AS, Argentou MN, Habeos IG, Makri MG, et al. Thyroid function in humans with morbid obesity. Thyroid. 2006;16(1):73-78. Doi:10.1089/thy.2006.16.73

43. Rotondi M, Leporati P, La Manna A, Pirali B, Mondello T, Fonte R, et al. Raised serum TSH levels in patients with morbid obesity: is it enough to diagnose subclinical hypothyroidism? Eur J Endocrinol. 2009;160(3):403-408. Doi:10.1530/EJE-08-0734

44. Choi SH, Lee YJ, Park YJ, Kim KW, Lee EJ, Lim S, et al. Retinol binding protein-4 elevation is associated with serum thyroid-stimulating hormone level independently of obesity in elderly subjects with normal glucose tolerance. J Clin Endocrinol Metab. 2008;93(6):23132318. Doi:10.1210/jc.2007-2536

45. Makepeace AE, Bremner AP, O’Leary P, Leedman PJ, Feddema P, 
Michelangeli V, et al. Significant inverse relationship between serum free T4 concentration and body mass index in euthyroid subjects: differences between smokers and nonsmokers. Clin Endocrinol (Oxf). 2008;69(4):648-652. Doi:10.1111/j.1365-2265.2008.03239.x

46. Peeters RP, van der Deure WM, van den Beld AW, van Toor H, Lamberts SW, Janssen JA, et al. The Asp727Glu polymorphism in the TSH receptor is associated with insulin resistance in healthy elderly men. Clin Endocrinol (Oxf). 2007;66(6):808-815. Doi:10.1111/j.13652265.2007.02817.x

47. Shon HS, Jung ED, Kim SH, Lee JH. Free T4 is negatively correlated with body mass index in euthyroid women. Korean J Intern Med. 2008;23(2):53-57

48. Biondi B, Cooper DS. The clinical significance of subclinical thyroid dysfunction. Endocr Rev. 2008;29(1):76-131. Doi: 10.1210/er.20060043

49. Bulow Pedersen I, Laurberg P, Knudsen N, Jorgensen T, Perrild H, Ovesen $\mathrm{L}$, et al. A population study of the association between thyroid autoantibodies in serum and abnormalities in thyroid function and structure. Clin Endocrinol (Oxf). 2005;62(6):713-720. Doi:10.1111/ j.1365-2265.2005.02284.x

50. Effraimidis G, Wiersinga WM. Mechanisms in endocrinology: autoimmune thyroid disease: old and new players. Eur J Endocrinol. 2014;170(6):R241-252. Doi:10.1530/EJE-14-0047

51. Duntas LH, Biondi B. The interconnections between obesity, thyroid function, and autoimmunity: the multifold role of leptin. Thyroid. 2013;23(6):646-653. Doi:10.1089/thy.2011.0499

52. Exley MA, Hand L, O'Shea D, Lynch L. Interplay between the immune system and adipose tissue in obesity. J Endocrinol. 2014;223(2):R4148. Doi:10.1530/JOE-13-0516

53. Gerriets VA, MacIver NJ. Role of T cells in malnutrition and obesity. Front Immunol. 2014;5:379. Doi: 10.3389/fimmu.2014.00379

54. Harpsoe MC, Basit S, Andersson M, Nielsen NM, Frisch M, Wohlfahrt J, et al. Body mass index and risk of autoimmune diseases: a study within the Danish National Birth Cohort. Int J Epidemiol. 2014;43(3):843855. Doi: 10.1093/ije/dyu045

55. MacIver NJ, Thomas SM, Green CL, Worley G. Increased leptin levels correlate with thyroid autoantibodies in nonobese males. Clin Endocrinol (Oxf). 2016;85(1):116-121. Doi:10.1111/cen.12963

56. Marzullo P, Minocci A, Tagliaferri MA, Guzzaloni G, Di Blasio A, De Medici $\mathrm{C}$, et al. Investigations of thyroid hormones and antibodies in obesity: leptin levels are associated with thyroid autoimmunity independent of bioanthropometric, hormonal, and weight-related determinants. J Clin Endocrinol Metab. 2010;95(8):3965-3972. Doi: 10.1210/jc.2009-2798

57. Matarese G, Leiter EH, La Cava A. Leptin in autoimmunity: many questions, some answers. Tissue Antigens 2007;70 (2):87-95. Doi:10.1111/j.1399-0039.2007.00886.x

58. Merrill SJ, Mu Y. Thyroid autoimmunity as a window to autoimmunity: An explanation for sex differences in the prevalence of thyroid autoimmunity. J Theor Biol. 2015;375:95-100. Doi:10.1016/j. jtbi.2014.12.015

59. Raoult D. Microbiota, obesity and malnutrition. Microb Pathog. 2017;106:1-2. Doi:10.1016/j.micpath.2016.02.001
60. Sharif K, Watad A, Bragazzi NL, Lichtbroun M, Amital H, Shoenfeld Y. Physical activity and autoimmune diseases: Get moving and manage the disease. Autoimmun Rev. 2018;17(1):539-72. Doi:10.1016/j. autrev.2017.11.010

61. Versini M, Aljadeff G, Jeandel PY, Shoenfeld Y. Obesity: an additional piece in the mosaic of autoimmunity. Isr Med Assoc J. 2014;16(10):619621

62. Versini M, Jeandel PY, Rosenthal E, Shoenfeld Y. Obesity in autoimmune diseases: not a passive bystander. Autoimmun Rev. 2014;13(9):9811000. Doi:10.1016/j.autrev.2014.07.001

63. Mariotti S, Sansoni P, Barbesino G, Caturegli P, Monti D, Cossarizza A, et al. Thyroid and other organ-specific autoantibodies in healthy centenarians. Lancet. 1992;339(8808):1506-1508.

64. Chiovato L, Lapi P, Fiore E, Tonacchera M, Pinchera A. Thyroid autoimmunity and female gender. J Endocrinol Invest 1993;16 (5):384-391. Doi:10.1007/BF03348863

65. Hollowell JG, Staehling NW, Flanders WD, Hannon WH, Gunter EW, Spencer CA, et al. Serum TSH, T(4), and thyroid antibodies in the United States population (1988 to 1994): National Health and Nutrition Examination Survey (NHANES III). J Clin Endocrinol Metab. 2002;87(2):489-499. Doi:10.1210/jcem.87.2.8182

66. Tunbridge WM, Evered DC, Hall R, Appleton D, Brewis M, Clark F, Evans JG, et al. The spectrum of thyroid disease in a community: the Whickham survey. Clin Endocrinol (Oxf). 1977;7(6):481-493

67. Delitala AP, Pilia MG, Ferreli L, Loi F, Curreli N, Balaci L, Schlessinger D, et al. Prevalence of unknown thyroid disorders in a Sardinian cohort. Eur J Endocrinol. 2014;171(1):143-149. Doi:10.1530/EJE-14-0182

68. Loviselli A, Oppo A, Velluzzi F, Atzeni F, Mastinu GL, Farci P, et al. Independent expression of serological markers of thyroid autoimmunity and hepatitis virus $\mathrm{C}$ infection in the general population: results of a community-based study in north-western Sardinia. J Endocrinol Invest. 1999;22(9):660-665. Doi:10.1007/BF03343626

69. Loviselli A, Velluzzi F, Mossa P, Cambosu MA, Secci G, Atzeni F, et al. The Sardinian Autoimmunity Study: 3. Studies on circulating antithyroid antibodies in Sardinian schoolchildren: relationship to goiter prevalence and thyroid function. Thyroid. 2001;11(9):849-857. Doi:10.1089/105072501316973109

70. Sardu C, Cocco E, Mereu A, Massa R, Cuccu A, Marrosu MG, et al. Population based study of 12 autoimmune diseases in Sardinia, Italy: prevalence and comorbidity. PLoS One. 2012;7(3):e32487. Doi:10.1371/journal.pone.0032487

71. Velluzzi F, Secci G, Sepe V, Klersy C, Shattock M, Foxon R, et al. Prediction of type 1 diabetes in Sardinian schoolchildren using islet cell auto antibodies: 10-year follow-up of the Sardinian schoolchildren type 1 diabetes prediction study. Acta Diabetol. 2016;53(1):73-79. Doi:10.1007/s00592-015-0751-y

72. Loviselli A, Ghiani ME, Velluzzi F, Piras IS, Minerba L, Vona G, et al. Prevalence and trend of overweight and obesity among Sardinian conscripts (Italy) of 1969 and 1998. J Biosoc Sci. 2010;42(2):201-211. Doi: $10.1017 /$ S0021932009990411

73. American Diabetes A. Standards of medical care in diabetes--2011. Diabetes Care. 2011;34(Suppl 1):S11-61. Doi:10.2337/dc11-S011 
74. Spencer CA, Hollowell JG, Kazarosyan M, Braverman LE. National Health and Nutrition Examination Survey III thyroid-stimulating hormone (TSH)-thyroperoxidase antibody relationships demonstrate that TSH upper reference limits may be skewed by occult thyroid dysfunction. J Clin Endocrinol Metab. 2007;92(11):4236-4240. Doi: $10.1210 / \mathrm{jc} .2007-0287$

75. Diez JJ, Iglesias P. Relationship between thyrotropin and body mass index in euthyroid subjects. Exp Clin Endocrinol Diabetes. 2011;119(3):144-150. Doi:10.1055/s-0030-1265133
76. Valdés S, Maldonado-Araque C, Lago-Sampedro A, Lillo-Muñoz J, Garcia-Fuentes E, Perez-Valero V, et al. Reference values for TSH may be inadequate to define hypothyroidism in persons with morbid obesity: Di@bet.es study. Obesity (Silver Spring) 2017;25(4):788-793. Doi:10.1002/oby.21796 